\title{
PENGEMBANGAN MODEL PEMBELAJARAN GUIDED PROJECT BASED LEARNING UNTUK MAHASISWA SLOWLEARNER
}

\section{Rahmat Kurniawan}

Sekolah Tinggi Informatika dan Komputer Indonesia Email: rahmat@stiki.ac.id, iwane14690@gmail.com

\begin{tabular}{l}
\hline Info Artikel \\
\hline Sejarah Artikel: \\
Diserahkan 6 November 2011 \\
Direvisi 7 Mei 2020 \\
Direvisi 22 Mei 2020 \\
Disetujui 29 Mei 2020 \\
\hline Keywords: \\
guided project based learning, \\
slow learners, \\
multimedia II course \\
\hline
\end{tabular}

\begin{abstract}
This research and development aims to developing a learning model Guided Project Based Learning that can be implemented for slow learners or slow learners or normal students in one learning environment. This model was applied in Multimedia II course in STIKI Malang visual communication design study program for five meetings.

The development method for developing this Guided Project Based Learning learning model uses the ADDIE model developed by Dick \& Carey. The steps of developing a learning model using the ADDIE development model consist of 5 steps, namely: 1) Analysis, 2) Design, 3) Development, 4) Implementation, 5) Evaluation. The sample in this study was the 5th semester visual communication design student where there were slowlearner students. Data was collected by mapping through the stages of psychological testing.

The results of the mapping found 1 student with special needs slow learner type. Implementation of the GPBL model proves students can understand the material and follow systematically the design of simple games. In addition, the student is actively able to explain game design concepts.
\end{abstract}

\begin{abstract}
Abstrak
Tujuan penelitian ini untuk mengembangkan model pembelajaran Guided Project Based Learning yang diimplemntasikan untuk mahasiswa slow learner atau lamban belajar maupun mahasiswa normal dalam satu rombongan belajar. Model ini diterapkan dalam mata kuliah Multimedia II pada program studi desain komunikasi visual STIKI Malang selama lima pertemuan.

Metode pengembangan untuk menyusun model pembelajaran Guided Project Based Learning ini menggunakan ADDIE model yang dikembangkan oleh Dick \& Carey. Langkah-langkah pengembangan model pembelajaran menggunakan model pengembagan ADDIE terdiri dari 5 langkah, yaitu: 1) Analisys, 2) Design, 3) Development, 4) Implementation, 5) Evaluation. Sampel dalam penelitian ini adalah mahasiswa desain komunikasi visual semester 5 dimana terdapat mahasiswa slowlearner. Data dikumpulkan dengan cara melakukan pemetaan melalui tahapan tes psikologi.

Hasil pemetaan ditemukan 1 mahasiswa berkebutuhan khusus bertipe slow learner. Implementasi model GPBL membuktikan mahasiswa dapat memahami materi dan mengikuti secara sistematis perancangan game sederhana. Selain itu, mahasiswa tersebut secara aktif mampu menjelaskan konsep-konsep perancangan game.
\end{abstract}




\section{PENDAHULUAN}

Dalam dunia pendidikan seorang pendidik selalu menghadapi peserta didik dengan karakteritik yang bermacam-macam. Karakteristik tersebut meliputi perbedaan tingkat kecerdasan, perilaku, maupun keadaan fisik. Dengan kondisi tersebut, setiap individu akan berbeda dalam membangun sikap dan pengetahuannya. $\mathrm{Di}$ sisi lain perbedaan karakteristik menjadi hambatan.

Hambatan tersebut tidak hanya dihadapi oleh seorang guru/dosen, namun juga oleh siswa atau mahasiswa. Hambatan tersebut bisa berupa hambatan fisik dan hambatan non fisik. Hambatan secara fisik misalnya adanya mahasiswa yang mengalami tuna netra, tuna rungu, dan tuna daksa. Hambatan non fisik misalnya gangguan emosi dan tingkah laku, gangguan perhatian, kesulitan belajar, cerdas istimewa dan lamban belajar.

Lebih lanjut lagi, berdasarkan hasil penelitian Amelia (2016). ditemukan bahwa perbedaan kemampuan motorik, kognitif, emosi antara laki-laki dan perempuan menimbulkan gangguan psikologis lebih banyak diderita oleh anak laki-laki dibanding anak perempuan, seperti kesulitan belajar (learning difficulties) lebih banyak dialami laki-laki, misalnya hambatan membaca (disleksia), hambatan menghitung (diskalkulia) dan hambatan menulis (disgrafia). Permasalahan ini hampir terjadi di semua lingkungan pendidikan.

Di lingkup perguruan tinggi, tidak sedikit mahasiswa berkebutuhan khusus, dalam kondisi ini lamban belajar atau slow learner. Mereka sulit dalam menyerap informasi secara utuh karena keterbatasan kemampuan kognitif. Permasalahan selanjutnya muncul ketika mereka berada diantara mahasiswa lain dengan kemampuan kognitif rata-rata atau diatas ratarata. Kondisi seperti ini tentu tidak mudah bagi seorang pengajar.

Mahasiswa yang lamban belajar (slow learner) memiliki kelemahan dalam berpikir, menemukan hubungan, penalaran, pengembangan konsep bilangan dan bahasa, serta ingatan. Anak slow learner memiliki kemampuan kognitif di bawah rata-rata, namun tidak bisa disebut dengan cacat (Borah, 2013). Namun demikian, anak yang lamban belajar memerlukan waktu yang lebih banyak dalam mengakuisisi kemampuannya dan akan lebih bermanfaat jika kegiatan pembelajaran dilakukan dengan terarah. Anak slow learner adalah mereka yang memiliki kemampuan koginitif rendah sehingga mengalami perlambatan dalam memproses informasi. Anak lamban belajar dengan IQ 80-90 lebih lambat dalam menangkap materi berupa simbol, abstrak atau materi konseptual. Kebanyakan anak mengalami kendala dalam materi membaca atau berhitung (Reddy et al, 2006).

Banyak faktor penyebab anak mengalami slow learner. Faktor tersebut bisa dari internal maupun eksternal. Faktor internal bisa disebabkan karena bawaan sejak lahir, pengaruh emosi, kondisi pikiran dan lain-lain. Sedangkan faktor eksternal bisa disebabkan karena lingkungan atau keluarga. Selain itu, faktor eksternal lain yang dimungkinkan bisa jadi penyebab anak mengalami lambat belajar karena cara belajar yang salah. Lebih lanjut Hopkins (2008) menyatakan bahwa faktor penyebab anak menjadi slow learner antara lain : 1) faktor keturunan; 2) perkembangan otak terbatas karena kurangnya rangsangan; 3 ) motivasi yang rendah; 4) masalah perhatian; 5) perbedaan latar belakang kebudayaan anak dengan sekolah; dan 6) kekacauan masalah pribadi.

Penelitian tentang kasus lamban belajar dilakukan Okfianto (2017) yang menunjukkan bahwa penyebab seorang anak lamban belajar disebabkan oleh faktor internal atau masalah pribadi yang bersangkutan. Faktor internal tersebut salah satunya adalah emosi. Masalah emosi ini menyebabkan anak lamban belajar memiliki prestasi belajar rendah, hubungan interpersonal yang buruk, dan konsep diri yang rendah (Reddy et al, 2006)

Penelitian sejenis juga dilakukan oleh Desiningrum (2006) yang menemukan fakta bahwa faktor eksternal yang justru menjadi penyebab utama anak lambat belajar yaitu bisa disebabkan oleh strategi pembelajaran yang salah atau tidak tepat, pengolahan kegiatan pembelajaran yang tidak membangkitkan motivasi belajar dan pemberian ulangan penguatan yang tidak tepat. Beberapa masalah yang dihadapi anak slow learner selama proses pembelajaran menurut Triana (2013) antara lain : 1) anak mengalami perasaan minder terhadap teman-temannya karena kemampuan belajarnya lamban jika dibandingkan teman- 
teman sebayanya. 2) anak cenderung bersifat pemalu dan cenderung menarik dari lingkungan sekitarnya. 3) lamban menerima infromasi karena keterbatasan dalam berbahasa reseptif atau menerima dan ekspresif atau mengungkapkan. 4) hasil belajar menjadi kurang optimal sehingga mengakibatkan anak menjadi stess karena ketidak mampuannya mencapai apa yang diharapkannya. 5) karena ketidak mampuannya mengikuti pelajaran dikelas, hal tersebut dapat membuat anak tinggal kelas. 6) mendapat label kurang baik dari teman-temannya.

Kasus seperti ini hampir dijumpai dibeberapa jenjang pendidikan seperti yang terjadi di STIKI Malang. Ada beberapa mahasiswa yang diduga mengalami kondisi lamban belajar. Berdasarkan hasil pemetaaan yang sudah dilakukan pada semua program studi di STIKI Malang menunjukkan bahwa ada sejumlah mahasiswa yang teridentifikasi slow learner.

Di program studi Desain Komunikasi Visual, terdapat mahasiswa yang terindikasi slow learner. Keterbatasan saat berinteraksi dengan mahasiswa yang bersangkutan bisa dirasakan dalam interaksi baik dengan teman sejawat maupun dengan pengajar. Berdasarkan pengalaman beberapa dosen yang pernah mengajar mahasiswa tersebut, kesulitan yang dialami adalah lambat dalam menangkap informasi dan kesulitan mencerna materi yang bersifat konseptual. Beberapa tugas mata kuliah belum terselesaikan dengan baik karena mispersepsi. Selain itu, ketika sedang berinteraksi secara personal, mahasiswa yang bersangkutan juga butuh waktu lama baik dalam mencerna informasi maupun dalam menyusun kata-kata. Dalam perilaku sosial, anak ini cenderung menyendiri dan kurang pandai dalam bergaul.

Berdasarkan pemaparan diatas maka perlu ada upaya dalam membantu mahasiswa slow learner untuk meningkatkan kemampuan berpikir serta daya tangkap terhadap materi, sehingga mampu bersaing dengan mahasiswa yang lain. Selain itu, upaya yang dilakukan mampu harus mampu memberikan efektivitas menyeluruh, bukan hanya kepada mahasiswa slow learner, namun juga mahasiswa yang lain. Salah satu upaya yang dilakukan yakni mengembangkan sebuah model pembelajaran.

Ardianti, Ulya, dan Ismaya (2018) menyatakan bahwa model pembelajaran merupakan kemasan lengkap dari semua kegiatan pembelajaran. Model pembelajaran mempunyai bagian di dalamnya, diantaranya yaitu pendekatan, strategi, metode, dan teknik pembelajaran. Lebih lanjut Suprihatiningrum (2013) menyebut model pembelajaran merupakan kerangka konseptual yang menggambarkan prosedur dalam mengorganisasikan pengalaman pembelajaran untuk mencapai tujuan pembelajaran. Model pembelajaran berfungsi sebagai pedoman bagi pengajar dalam merencanakan dan melaksanakan kegiatan pembelajaran.

Secara kemampuan kognitif, mahasiswa slow learner mengalami kesulitan dalam memahami materi yang berupa konsep-konsep dan lebih mudah memahami persoalanpersoalan konkrit dan sederhana. Mereka tampil di tingkat yang lebih tinggi ketika informasi disajikan secara konkret. Semakin abstrak konsep atau teknik pengajaran, semakin sulit bagi mereka untuk belajar (Shaw, 2010). Selain itu, penekanan pada pengulangan dan pendampingan berperan penting agar materi bisa benar-benar dipahami oleh mahasiswa yang bersangkutan.

Dibutuhkan sebuah model belajar yang bisa membantu mahasiswa yang mengalami masalah lambat dalam belajar, agar bisa mencapai kompetensi perkuliahan. Selain itu juga diperlukan desain pembelajaran yang menumbuhkan sikap empati dan kerjasama (Pratiwi, Ardianti, dan Kanzunnudin, 2018) antar individu agar meningkatkan rasa percaya diri (Rahayu, 2015) mahasiswa slow learner.

\section{METODE PENELITIAN}

Jenis penelitian ini termasuk dalam jenis penelitian pengembangan (research and development). Sedangkan produk penelitian ini berupa model pembelajaran yang dalam pelaksanannya diterapkan pada mata kuliah multimedia II (Animasi 3D) program studi desain komunikasi visual di STIKI Malang. Proses pengembangan media ini menggunakan $A D D I E$ models yang dikembangkan oleh Dick and Carey.

Model pengembangan instruksional ini cukup mudah diaplikasikan pada berbagai content pengembangan. Hal ini sejalan dengan pendapat (Aldoobie, 2015) bahwa model ini adalah pendekatan yang membantu perancang 
instruksional, pengembang konten apapun, atau bahkan pengajar untuk membuat desain pengajaran yang efisien dan efektif dengan menerapkan proses model $A D D I E$ pada produk instruksional apapun.

Adapun tahapan-tahapan dalam penelitan dan pengembangan model pembelajaran ini meliputi Analisys, Design, Develelop, Implementation, and Evaluation. Tahapan analysis dilakukan untuk menganalisa tentang (1) permasalaan yang terjadi. (2) apakah model pembelajaran mampu mengatasi masalah pembelajaran yang dihadapi; (3) apakah model mendapat dukungan fasilitas untuk diterapkan; (4) apakah dosen mampu menerapkan model pembelajaran baru.

Pada tahap design, dosen menetapkan tujuan pembelajaran, merancang kegiatan belajar mengajar, merancang perangkat pembelajaran, merancang materi pembelajaran dan alat evaluasi hasil belajar. Rancangan pada kedua model telah dijelaskan pada subbab rancangan model inovasi yang akan dihasilkan.

Tahap Development meliputi kegiatan dalam menyusun perangkat pembelajaran mulai dari RPP, media pembelajaran, dan penilaian capaian kompetensi pembelajaran. Tahap keempat adalah tahap Implementation. Tahap ini adalah proses penerapan model pembelajaran untuk mengetahui sejauh mana efektivitas dari model yang dikembangkan. Penerapan model pembelajaran ini dilakukan di bulan September 2019. Uji coba dilakukan kepada kepada mahasiswa program studi Desain Komunikasi Visual Angkatan 2017 di STIKI Malang pada mata kuliah Multimedia II. Mahasiswa yang teridentifikasi slow learner sejumlah satu orang dari total 25 mahasiswa.

Tahap yang terakhir yakni tahap Evaluation. Pada tahap ini, penilaian dilakukan di setiap akhir pertemuan dan akhir semester. Hal-hal yang perlu dibahas pada tahap ini adalah: a) Melihat kembali dampak pembelajaran dengan cara kritis b) Mengukur ketercapaian tujuan pengembangan produk c) Mengukur apa yang telah mampu dicapai oleh sasaran d) Mencari informasi apa saja yang dapat membuat peserta didik mencapai hasil dengan baik.

Pengukuran keberhasilan dari Model GPBL ini dapat dilihat dari laporan setiap tugas yang diberikan dan mahasiswa yang bersangkutan mampu menjelaskan konsep/ide yang akan dijadikan sebagai karya, sekaligus mampu memaparkan dan menjalankan proses produksi secara sistematis. Perhitungan skor tim dilakukan dengan cara menjumlahkan masing-masing skor peningkatan individu dan hasilnya dibagi sesuai jumlah anggota kelompok.

\section{HASIL DAN PEMBAHASAN}

Sesuai tahapan ADDIE Model, tahap pertama adalah melakukan analisis. Tahap analisis adalah fase paling penting dalam proses ini. Untuk melaksanakan tahap analisis kita harus menganalisis empat hal, seperti kita harus menganalisis peserta didik (di mana mereka berada, keterampilan dan kebutuhan mereka (Aldoobie, 2015).

Dalam menyusun sebuah model pembelajaran, terlebih dahulu harus mengidentifikasi masalah dan kondisi yang terjadi. Analisis kebutuhan merupakan tahap untuk mengetahui karakteristik dan kendala yang dialami peserta didik dalam proses belajar sebelum merancang sebuah model pembelajaran yang efektif bagi mahasiswa berkebutuhan khusus.

Dalam kasus slow learner, secara fisik dan pergaulan tidak menunjukan perbedaan dengan anak normal pada umumnya (Marheni, 2017). Oleh karena itu perlu dilakukan pemetaan untuk mengidentifikasi secara jelas siapa saja mahasiswa yang diduga slow learner. Identifikasi tersebut meliputi kelebihan dan kekurangan, minat belajar, keterampilan, konsep diri, interaksi sosial serta aspek spesifik lain seperti perkembangan kognitif, motorik, dan afektif.

Proses pemetaan atau klasifikasi dapat dilakukan dengan cara melakukan semacam asesmen. Tahap asesmen dapat dilakukan dengan cara melakukan pengamatan selama proses pembelajaran atau menggunakan serangkaian tes sebagai instrumen. Hal ini bertujuan untuk mengetahui peserta didik yang bersangkutan termasuk dalam golongan anak berkebutuhan khusus tipe apa. Tahap ini perlu dilakukan sebagai langkah awal dalam memprogram sebuah desain pembelajaran. Dengan demikian, akan lebih mudah untuk menentukan dan mengembangkan tipe model pembelajaran sesuai yang diharapkan.

Berdasarkan hasil pemetaan psikologis terhadap mahasiswa semua program studi 
angkatan 2016-2018 di STIKI, terdapat sejumlah mahasiswa yang terduga sebagai mahasiswa berkebutuhan khusus. Kriteria yang menjadi acuan penilaian meliputi Kecerdasan Umum (KU), Daya Analisa (DA), Pertimbangan Sosial (PS), dan Logika berpikir (LB).

Khusus program studi Desain Komunikasi Visual terdapat satu mahasiswa yang tergolong mahasiswa berkebutuhan khusus bernama RG (inisial mahasiswa terindiksi slow learner). Data Hasil tes menunjukkan beberapa kriteria diatas, mahasiswa yang bersangkutan memperoleh rata-rata skor dibawah 4 . Sedangkan untuk skor IQ menunjukkan berada pada rentang antara 80-89. Berdasarkan data diatas menunjukkan bahwa mahasiswa yang bersangkutan tergolong dalam kategori slow learner atau lambat belajar.

Setelah melakukan proses identifikasi kebutuhan, langkah selanjutnya adalah mendesain model pembelajaran. Model pembelajaran adalah suatu perencanaan atau pola yang digunakan sebagai pedoman dalam merencanakan pembelajaran di kelas atau pembelajaran tutorial (Trianto, 2011). Model pembelajaran mengacu pada pendekatan pembelajaran yang akan digunakan, termasuk di dalamnya tujuan-tujuan pengajaran, tahaptahap dalam kegiatan pembelajaran, lingkungan pembelajaran, dan pengelolaan kelas.

Salah satu model yang sering digunakan adalah model pembelajaran kooperatif atau cooperative learning. Pembelajaran kooperatif adalah model belajar dengan membagi peserta didik menjadi beberapa kelompok, tujuannya agar masing-masing mereka bisa bekerja sama dalam satu kelompok. Dalam pembelajaran kooperatif ini peserta didik diajarkan bagaimana bekerja sama, saling memimpin, saling bertanggung jawab dalam kesetaraan pembelajaran yang senasib dan sepenanggungan, menciptakan hubungan saling mendukung antar personal, membantu dan saling peduli dalam mencapai tujuan yaitu keberhasilan dalam menguasai materi belajar (Suparmi, 2012).

Berdasarkan riset Hartini, et al (2017) diketahui bahwa dengan model ini peserta didik lamban belajar akan melakukan interaksi sosial yang mengharuskannya terlibat aktif selama pembelajaran, maka perlu partisipasi teman-teman yang aktif mengundangnya untuk berpartisipasi, sehingga peserta didik lambat akan memiliki keterampilan sosial yang baik pula. Namun model ini belum diujicobakan untuk tingkat perguruan tinggi.

Salah satu model pembelajaran kooperatif yang mudah diadaptasi adalah model pembelajaran tipe STAD (Student Teams-Achievement Divisions). Pembelajaran STAD merupakan salah satu dari tipe pembelajaran kooperatif yang paling sederhana, sehingga tipe ini dapat digunakan oleh pengajar yang baru mulai menggunakan pembelajaran kooperatif (Slavin, 2010).

Tipe STAD merupakan salah satu tipe kooperatif yang menekankan pada adanya aktivitas dan interaksi diantara siswa untuk saling memotivasi dan saling membantu dalam menguasai materi pelajaran guna untuk mencapai prestasi yang maksimal. Pembelajaran kooperatif tipe STAD merupakan salah satu tipe dari model pembelajaran kooperatif dengan menggunakan kelompokkelompok kecil dengan jumlah anggota tiap kelompok 4-5 orang siswa secara heterogen (Trianto, 2007).

Model pembelajaran STAD sudah banyak diaplikasikan ke berbagai bentuk pembelajaran karena dinilai cukup efektif dalam meningkatkan kualitas belajar. Riset Oktavianti dan Santoso (2014), penelitian Suratmi (2016), riset Wuryanto (2016) dan penelitian Suryana (2018) merupakan bukti bahwa model STAD sangat efektif dalam meningkatkan kualitas belajar. . Menurut hemat peneliti model ini dirasa perlu diadaptasi atau dikembangkan menjadi model pembelajaran baru yang mampu mengakomodasi kebutuhan seluruh mahasiswa termasuk di dalamnya mahasiswa slow learner.

Dalam kasus slow learner, jenis model yang dibutuhkan adalah model pembelajaran kooperatif dan berbasis tutorial untuk memberikan gambaran materi-materi secara konkrit sekaligus menekankan pada kegiatan pendampingan. Salah satu pembelajaran yang dapat membuat mahasiswa mendapatkan pembelajaran secara konkret adalah pembelajaran Project Based Learning. Menurut Grant (2002) project based learning atau pembelajaran berbasis proyek merupakan model pembelajaran yang berpusat pada peserta didik untuk melakukan suatu 
investigasi yang mendalam terhadap suatu topik. Sejalan dengan pendapat tersebut, Wajdi (2017) menyatakan bahwa pembelajaran berbasis proyek merupakan pendekatan pendidikan yang efektif dan berfokus pada kreatifitas berpikir, problem solving, dan interaksi antara siswa dengan kawan sebaya mereka untuk menciptakan dan menggunakan pengetahuan baru. Sementara itu Ardianti et al (2017) mengemukakan project based learning (PjBL) merupakan salah satu model pembelajaran yang bercirikan adanya kegiatan merancang dan melakukan sebuah proyek untuk menghasilkan sebuah produk.

Sejalan juga dengan prinsip konstruktivistik yang menyatakan bahwa pembelajaran seharusnya merupakan proses seorang individu membangun pengetahuan melalui pembelajaran aktif, pembelajaran melalui proses berpikir, pembelajaran bermakna dan pembelajaran dengan bereksplorasi (Patil et al, 2017). Pembelajaran berbasis project ini membantu mahasiswa untuk belajar secara bermakna (Meaningful learning) dan mendalam (deep learning) karena secara langsung dihadapkan kasus sehingga bisa mendapatkan pengalaman secara konkret. Dengan kata lain, pengetahuan dikontruksi berdasarkan pengalaman interaksi langsung antara pebelajar dengan objek belajar.

\section{Model Pembelajaran Guided Project Based Learning}

Dalam penelitian dan pengembangan ini model yang dikembangkan adalah model pembelajaran guided project based learning. Model pembelajaran GPBL merupakan desain model pembelajaran dengan cara mengintegrasikan STAD dan Project Based Learning namun dengan pendekatan inklusi.

Model ini adalah jenis model pembelajaran berbasis kelompok namun lebih menekankan pada aktivitas individu yang mendampingi mahasiswa slow learner secara khusus. Tujuan pengembangan model ini adalah untuk membantu mahasiswa slow learner dalam meningkatkan kemampuan kognitif dan meningkatkan pemahaman setiap materi dalam perkuliahan.

Perbedaan model ini dengan model kooperatif sebelumnya terletak pada adanya Guided (pendampingan) dan pengulangan dalam setiap pertemuan. Pendampingan dilakukan oleh tutor atau teman sebaya dalam kelompok. Perbedaan selanjutnya adalah terletak pada proses treatment yang dilakukan. Mahasiswa slow learner memiliki kapasitas kognitif yang terbatas sehingga membuatnya kesulitan mengingat dan mencerna informasi. Butuh pengulangan informasi agar informasi diterima secara utuh. Oleh karena itu, dibutuhkan pendampingan secara khusus baik dari dosen maupun dari teman serta penugasan pribadi untuk menguatkan pemahaman mahasiswa slow learner dalam belajar

Model guided project based learning dikembangkan untuk membantu si pebelajar (mahasiswa slow learner) agar mampu memahami materi yang diberikan secara utuh serta mampu mencapai kompetensi pembelajaran. Beberapa manfaat yang diperoleh mahasiswa slow learner melalui penerapan model ini antara lain yakni 1) membantu mahasiswa berkebutuhan khusus untuk mencapai kompetensi yang diharapkan dalam mata kuliah dengan model pembelajaran terintegrasi, 2) membantu meningkatkan inisiatif belajar dan kemampuan kognitif mahasiswa berkebutuhan khusus, 3) membantu meningkatkan kemampuan mahasiswa berkebutuhan khusus dalam berinterkasi sosial dengan teman sejawat, 4) membantu mahasiswa berkebutuhan khusus agar lebih aktif dan mandiri dalam menyelesaikan tugastugas perkuliahan, 5) meningkatkan rasa percaya diri anak karena berani unjuk gigi dalam mempresentasikan materi.

Ada beberapa cara yang bisa dilakukan untuk mendukung anak slow learner dalam mencapai kompetensi pembelajaran (Shaw, 2010) meliputi : 1). Menggunakan instruksi konkret. 2) Memberikan kesempatan berupa pengulangan dan praktik keterampilan diskrit yang sering diterapkan pada setiap tugas. 3) Membantu siswa mengembangkan keterampilan manajemen waktu dan organisasi dasar. 4) Menyederhanakan bentuk tugas. 5) Pemberian reward. 6) Menyediakan berbagai cara agar anak mencapai kompetensi. 7) adanya pendampingan oleh mentor sebaya. 8) Melakukan pembelajaran bermakna. Model GPBL diterapkan pada mata kuliah multimedia II yang menuntut mahasiswa untuk membangun konsep dan memahami instruksi dalam menghasilkan sebuah karya. 


\section{Kerangka Model Pembelajaran GBPL}

Dalam pelaksanaannya mahasiswa dibentuk menjadi beberapa kelompok. Setiap kelompok terdiri $3-5$ orang dengan beragam karakteristik (termasuk satu anak slow learner). Setiap kelompok akan diberi topik yang berbeda. Masing-masing topik didiskusikan kemudian ditanggapi oleh masing-masing individu dari sudut pandang yang berbeda. Gunanya adalah untuk memperkaya wawasan topik yang didiskusikan.

Dalam tahap diskusi, hasil analisis masing-masing siswa harus berbeda satu sama lain. Pada saat melakukan kegiatan tinjauan, masing-masing individu harus saling membantu dan memotivasi satu sama lain. penilaian yang dilakukan yakni berdasar kan laporan individu dan kelompok. Kelompok dengan hasil analisis terbaik akan mendapatkan reward dari dosen pengampu mata kuliah. Kemudian untuk materi yang sifatnya instruksional, dosen pengampu diharapkan melakukan pendampingan secara personal, memberi instruksi secara sederhana.

Pendampingan juga bisa dilakukan oleh mahasiswa yang memiliki kemampuan diatas mahasiswa yang lain sebagai modeling. Dosen bisa menugaskan mahasiswa tersebut untuk membantu menjelaskan ulang tahap-tahap pembuatan karya kepada mahasiswa slow learner. Ada 3 bentuk pengulangan pembelajaran yakni, 1) melalui video tutorial 2) pendampingan oleh tutor sebaya kelompok 3) tugas mingguan baik individu dan kelompok.

Berdasarkan hasil validasi oleh dua orang ahli terhadap model pembelajaran Guided Project Based Learning mendapat skor $80 \%$ dan $85 \%$, dengan demikian model pembelajaran ini mempunyai kelayakan untuk diterapkan pada kegiatan pembelajaran.

\section{Pelaksanaan Model Pembelajaran}

1) Penyampaian tujuan dan motivasi. 2) pembelajaran melalui video tutorial. 3) Dosen membagi kelompok berdasarkan keberagaman. 4) Mahasiswa dibagi menjadi beberapa kelompok. Masing-masing kelompok terdiri dari 3-5 orang. 5) Kerja Tim. Tahap ini, Dosen memberikan bahasan yang berbeda pada masing-masing kelompok.

Pokok bahasan tersebut kemudian diulas dalam kelompok. Setelah selesai, salah satu anggota saling membacakan ide dan gagasannya. Sedangkan anggota yang lain menyimpulkan ide-ide anggota lainnya sehingga masing-masing anggota memperoleh pemahaman secara utuh. Begitu pula dengan kelompok lainnya.

Dalam kegiatan produksi, Dosen maupun teman sejawat untuk melakukan pendampingan dan pengawasan secara khusus selama proses produksi. Untuk deadline proses produksi disamakan dengan mahasiswa yang lain. Mahasiswa yang ditugaskan untuk mendampingi harus bisa menjelaskan ulang materi yang sudah diberikan dosen.

Khusus mahasiwa slow learner, materi sederhana namun capaian pembelajaran disamakan dengan mahasiswa yang lain. 5). Evaluasi : Setelah semua mahasiswa selesai menyampaikan hasil tulisannya, dosen memberi masukan pada masing-masing bahasan yang belum dipahami mahasiswa.

Kemudian mahasiswa menyerahkan laporan berupa laporan individu dan laporan kelompok. Khusus mahasiswa slow learner diberi tugas tambahan untuk me-resume kembali materi yang sudah dipelajari didalam kelas.

Dari hasil pengamatan terhadap implementasi model dapat dijelaskan sebagai berikut : pertemuan pertama, dalam tahap apersepsi, dosen mencoba menjelaskan deskripsi matakuliah serta menjelaskan kompetensi yang harus dicapai. Setelah tahap penyampaian materi, dosen menyuruh mahasiswa untuk membuat kelompok sebanyak 5 kelompok.

Dalam rombongan belajar mata kuliah multimedia II terdapat sekitar 25 anak, dan satu diantaranya adalah mahasiwa slow learner. Mahasiswa membentuk 5 kelompok dengan masing-masing kelompok terdiri dari 5 anggota secara heterogen. Mahasiswa mendapat tugas untuk memikirkan konsep game sederhana yang akan dirancang. Mahasiswa diminta untuk melihat video tutorial yang sudah disajikan di E-belajar STIKI. Pada saat mengamati video, RG terlihat menyimak dengan seksama dan nampak beberapa waktu mengulang videonya.

Pertemuan kedua, masing-masing kelompok menjelaskan konsep game yang akan dibuat. Khusus kelompok yang anggotanya terdapat mahasiwa slowlearner, mahasiswa tersebut yang diminta untuk menjelaskan konsep apa yang kemudian diwujudkan ke 
Rahmat Kurniawan

PENGEMBANGAN MODEL PEMBELAJARAN GUIDED PROJECT BASED LEARNING ... REFLEKSI EDUKATIKA : Jurnal Ilmiah Kependidikan, Volume 10, Nomor 2, Juni 2020, hlm. 144-153

dalam game sederhana.

Pada saat menjelaskan, mahasiswa sedikit terbata-bata dalam menyampaikan ide kelompoknya. Namun secara keseluruhan mahasiswa ini mampu menjelaskan secara sistematis dibantu oleh teman sejawat maupun dosen. Proses ini membantu mahasiswa tersebut untuk belajar lebih mendalam dan berulang-ulang. Diakhir pertemuan dosen secara khusus memberikan tugas untuk menuliskan ulang konsep beserta kerangka kerja yang akan digunakan dalam proses pembuatan game sederhana.

Pertemuan ketiga, kelompok melanjutkan project untuk mewujudkan gagasan kedalam proses produksi. Masingmasing anggota dalam kelompok mendapat tugas sesuai jobdesk selama saat proses produksi. Khusus untuk kelompok yang terdapat mahasiswa slow learner terlihat saling membantu sama lain. Anggota yang lain secara kooperatif mendampingi dan membimbing RG bergantian. Selain itu, mahasiswa tersebut terlihat aktif bertanya pada anggota yang mendampingi. Proses pendampingan masih dilakukan sampai 5 pertemuan seperti yang terlihat pada gambar 1 .

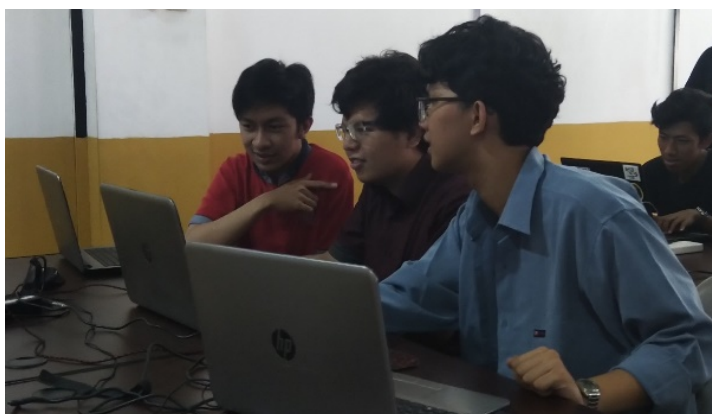

Gambar 1. Proses pendampingan oleh teman sejawat

Pertemuan keempat, pertemuan ini membahas tentang mekanisme menembak pada permainan menembak (shooter game). Guna memudahkan penyampaian materi serta menjalin kekompakan dalam tim, proses penyampaiannya dilakukan dikelas oleh dosen, tetapi untuk latihan pengerjaan mekanisme menembak dilakukan dalam kelompok.

Selanjutnya, RG diberi tugas untuk mengerjakan proses yang tidak dapat diselesaikan dikelas untuk dilanjutkan secara mandiri dengan bimbingan teman kelompok. Selain itu, RG juga diberi tugas tambahan untuk Kembali me-resume hasil kegiatan pembelajaran pada pertemuan tersebut.

Pertemuan kelima, mahasiswa diminta untuk berdiskusi untuk mengembangkan konsep permainan sederhana dari hasil latihan yang sudah dilakukan pada pertemuan sebelumnya. Pada saat presentasi, RG terlihat aktif dan sistematis dalam menjelaskan mekanisme game yang telah dirancang. Walaupun sedikit terbata-bata, RG dengan percaya diri menjelaskan hasil kerja kelompok. Hal ini karena adanya treatment pembiasaan dari dosen kepada mahasiswa agar bisa menjelaskan kepada anggota yang lain.

Hasil evaluasi berdasarkan hasil penilaian dosen dari penerapan Model pembelajaran Guided Project Based Learning pada mata kuliah mata kuliah Multimedia II berupa tugas project dan penilaian individu tiap pertemuan. RG mampu mengejawantahkan tugas dengan cukup baik. RG memahami secara keseluruhan materi dan dianggap telah mencapai kompetensi dalam mata kuliah Multimedia II.

Keunggulan dari model pembelajaran ini dari pada model sebelumnya adalah adanya perilaku saling membantu dan memotivasi antar anggota satu sama lain. Anggota kelompok harus bersedia membantu anggota yang lain yang mengalami kesulitan dalam memahami konsep. Selain itu model ini juga menekankan pada pengulangan materi baik dari pendampingan maupun dengan pemberian tugas oleh dosen yang dengan tujuan mahasiswa slow learner benar-benar memahami konsep.

Hasil riset yang dilakukan memiliki persamaan dan perbedaan dengan riset Oktavianti dan Santoso (2014), penelitian Suratmi (2016), riset Wuryanto (2016), penelitian Almujab et al (2018), serta riset Pratiwi, Ardianti, dan Kanzunnudin (2018). Persamaannya yaitu pada pemilihan model PjBL dan STAD dalam pembelajaran. Sedangkan perbedaannya yakni pada hasil riset yang ditemukan karena adanya perbedaan metode, subyek, dan yang utama yaitu perbedaan rumusan masalah.

Riset Oktavianti dan Santoso (2014) menyimpulkan bahwa penerapan model pembelajaran cooperative learning tipe STAD 
dan Snowball Drilling kelas III SD Tumpangkrasak 2 Kudus dapat meningkatkan keaktifan dan prestasi belajar IPS. Sementara itu penelitian Suratmi (2016) menyimpulkan bahwa Penerapan metode pembelajaran STAD (Student Teams - Achievement Divisions) dan menggunakan CD Pembelajaran dalam pembelajaran IPA materi struktur dan fungsi bagian tumbuhan siswa kelas IV SD $\mathrm{N}$ Karangtowo Kec. Karangtengah Kab. Demak dapat meningkatkan prestasi belajar siswa.

Lebih lanjut riset Wuryanto (2016) menyimpulkan bahwa Penerapan metode pembelajaran STAD (Student Teams Achievement Devisions) dan menggunakan media video dalam pembelajaran IPA materi struktur dan fungsi bagian tumbuhan siswa kelas IV SD N Babadan Kec. Bonang Kab. Demak dapat meningkatkan prestasi belajar siswa.

\section{SIMPULAN}

Model pembelajaran Guided Project Based Learning yang diterapkan pada mata kuliah Multimedia II program studi Desain Komunikasi Visual STIKI Malang mempunyai dampak peningkatan baik pada proses dan hasil belajar mahasiswa slowlearner. Ke depannya, tidak menutup kemungkinan jika model ini bisa diterapkan pada skala yang lebih besar.

Model ini efektif diterapkan bagi mahasiwa yang kesulitan untuk mengolah informasi yang bersifat konseptual dengan baik, dan cenderung mudah menerima informasi yang konkrit dan sederhana. Dari hasil uji coba dapat disimpulkan bahwa mahasiswa berkebutuhan khusus secara konseptual dan praktis mampu menguasai materi dan menerapkan dalam rancangan game cukup baik. Hasil kerja individu dan kelompok cukup memuaskan.

Hal yang harus diperhatikan dalam menerapkan model ini adalah jumlah anggota dalam kelompok dengan beban tugas harus proporsional. Jika beban tugas banyak maka jumlah anggota kelompok harus banyak, agar beban dan tanggung jawab pendampingan oleh teman sejawat tdak berat.

\section{UCAPAN TERIMA KASIH}

$\begin{array}{rrr}\text { Terima } & \text { kasih kepada } & \text { Direktorat } \\ \text { Pembelajaran, } & \text { Direktorat } & \text { Jenderal } \\ \text { Pembelajaran } & \text { dan } & \text { Kemahasiswaan }\end{array}$

Kementerian Riset Teknologi, \& Pendidikan Tinggi sebagai Lembaga yang mendanai dan menginisiasi program pengembangan inovasi pembelajaran ini. Terima kasih kepada tim di STIKI Malangyang terlibat dan berkontribusi dalam pengembangan model inovasi pembelajaran ini.

\section{DAFTAR PUSTAKA}

Aldoobie, N. 2015. ADDIE MODELS. American International Journal of Contemporary Research, 68-72.

Ardianti, S.D., Pratiwi, I.A., dan Kanzunnudin, Moh. 2017. Implementasi Project Based Learning (PjBL) Berpendekatan Science Edutainment Terhadap Kreativitas Peserta Didik. Refleksi Edukatika : Jurnal Ilmiah Kependidikan, 7 (2): 145150.

Ardianti, Sekar Dwi., Ulya, Himmatul., dan Ismaya, Erik Aditia. 2018. PAKEM DALAM KURIKULUM 2013 : Teori dan Praktek. Kudus: Badan Penerbit Universitas Muria Kudus.

Desiningrum, Ratri D. 2006. Psikologi Anak Berkebutuhan Khusus. Psikosain.

Grant. 2002. Getting A Grip of Project Based Learning: Theory, Cases and Recomandation. Meredian A Middle School Computer Technologies, 5.

Hartini, et al. 2017. Learning Strategies For Slow Learners Using The Project Based Learning Model In Primary School. Jurnal Pendidikan Inklusi, 1: 029-039.

Okfianto, E. 2017. Analisis Faktor Penyebab Siswa Terindikasi Lamban Belajar Di SDN Percobaan 4 Wates Kulonprogo. Jurnal Pendidikan Guru Sekolah Dasar, 07.

Hopkins, B. 2008. The Child Who is a Slow Learner. Teachers Resource Manual. State University of New York.

Marheni, K. I. 2017. Art therapy bagi anak slow learner. Prosiding Temu Ilmiah X 
Rahmat Kurniawan

PENGEMBANGAN MODEL PEMBELAJARAN GUIDED PROJECT BASED LEARNING ...

REFLEKSI EDUKATIKA : Jurnal Ilmiah Kependidikan, Volume 10, Nomor 2, Juni 2020, hlm. 144-153

Ikatan Psikologi Perkembangan Indonesia, 154-162.

Oktavianti, Ika dan Santoso, S. 2014. Penerapan Cooperative Learning Tipe STAD dan Snowball Drilling Untuk Meningkatkan Keaktifan dan Prestasi Belajar IPS. Refleksi Edukatika : Jurnal Ilmiah Kependidikan, 4 (2).

Patil, et al. 2017. Teaching Learning with Constructivist Approach. International Journal of Engineering Development and Research, 308-312.

Pratiwi, Ika Ari., Ardianti, Sekar Dwi., dan Kanzunnudin, Moh. 2018. Peningkatan Kemampuan Kerjasama Melalui Model Project Based Learning (PJBL) Berbantuan Metode Edutainment Pada Mata Pelajaran Ilmu Pengetahuan Sosial. Refleksi Edukatika : Jurnal Ilmiah Kependidikan, 8 (2): 177-182.

Rahayu, Ratri. 2015. Faktor-Faktor Yang Mempengaruhi Kepercayaan Diri Siswa Kelas VIII Dalam Menyelesaikan Masalah Matematika Pada Model PMRI. Refleksi Edukatika : Jurnal Ilmiah Kependidikan, 5 (2).

Reddy G , et al. 2006. Slow Learners: Their Psychology and Instruction. Discovery Publishing House.

RR Borah. 2013. Slow Learners: Role of Teachers and Guardians in Honing Hidden Skils. International Journal of Educational Planning\&Administration, Volume 3, 139-143.

Shaw, S. R. 2010. Rescuing Students from the Slow Learner Trap. In Principal Leadership. National Association of Secondary School Principal.

Slavin. 2010. Cooperative Learning Teori, Riset dan Praktik. Nusa Media Provus.
Suparmi. 2012. Pembelajaran Kooperatif Dalam Pendidikan Multikultural. Jurnal Pembangunan Pendidikan: Fondasi Dan Aplikasi, 1(1): 109-118.

Suprihatiningrum, J. 2013. Strategi Pembelajaran Teori \& Aplikasi. Yogyakarta : Ar-Ruzz Media.

Suratmi, S. 2016. Meningkatkan Prestasi Belajar IPA Dengan Menerapkan Metode Student Teams Achievement Divisions Berbantuan CD Pembelajaran Pada Siswa Kelas Iv Semester 1 di SD N Karangtowo. Refleksi Edukatika : Jurnal Ilmiah Kependidikan, 7 (1).

Suryana, Y. R. \& D. 2018. Kajian Model Pembelajaran Kooperatif Tipe STAD (Student Teams Achievement Division) Dalam Upaya Meningkatkan Efektifitas Proses Belajar Mengajar Akuntansi. Jurnal Kajian Pendidikan Ekonomi Dan Ilmu Ekonomi, 2: 133-145.

Trianto. 2007. Model-model Pembelajaran Inovatif Berorientasi Konstruktivistik. Jakarta : Prestasi Pustaka Publisher.

Trianto. 2011. Mendesain Model Pembelajaran Inovatif-Progresif: Konsep, Landasan, dan Implikasinya pada Kurikulum Tingkat Satuan Pendidikan (KTSP). Yogyakarta : Kencana.

Wachyu Amelia. 2016. Karakteristik dan Jenis Kesulitan Belajar Anak Slow Learner. Jurnal Ilmu Kesehatan Aisyah, 1(2): 53-58.

Wajdi, F. 2017. Implementasi Project Based Learning ( $\mathrm{Pbl}$ ) Dan Penilaian Autentik Dalam Pembelajaran Drama Indonesia. Jurnal Pendidikan Bahasa Dan Sastra, 17: 81-97.

Wuryanto, W. 2016. Meningkatkan Prestasi Belajar IPA Dengan Media Video Dan Metode STAD Semester 1 Kelas IV SDN Babadan Tahun 2015/2016. Refleksi Edukatika : Jurnal Ilmiah Kependidikan, 6 (2). 